\title{
The Utilization of Air Conditioning Heat Waste as Cloth Drying Energy Source
}

\author{
Sarono Widodo ${ }^{\mathrm{a}}$ and Gatut Rubiono ${ }^{\mathrm{b}}$ \\ aPoliteknik Negeri Semarang, Central Java, 50275 Indonesia \\ bUniversitas PGRI Banyuwangi, East Java, 68418 Indonesia \\ e-mail:sarono.widodo@polines.ac.id,g.rubiono@fdi.or.id
}

\begin{abstract}
Air Conditioning (AC) as an air conditioner has been used on one side only as a room cooling. The cooling process with Air Conditioning produces heat as a result of the work of the condenser component in the AC. This heat can be used as an alternative energy source. This study aims to utilize hot air discharging Air Conditioning as an energy source for drying clothes. This development is based on the Thosiba AC specification. The specification data is used to get the coefficient of performance (COP) and heating effect. Development is also carried out for studies in the form of experiments. The results of the study indicate that the application of $A C$ exhaust heat has the potential to be developed as an alternative energy in the process of drying clothes.
\end{abstract}

Keywords: Air Conditioning; alternative energy; cloth drying; heat air

\section{INTRODUCTION}

The process of drying clothes is one of the essential problems in Indonesia. The condition of two seasons in a year where one of them is the rainy season for approximately six months is a constraint to conventional drying which utilizes direct solar heat. Drying of clothes is still a lot of immediate use of solar heat which according to the Meteorology and Geophysics Agency, the temperature of the sun during the day ranges between $33^{\circ} \mathrm{C}-39^{\circ} \mathrm{C}[1,2]$. Drying of clothing is generally carried out with a rope and allowed to dry for at least two to three hours due to moisture [3].

Drying clothing using solar and wind energy has been developed for drying clothes that use electrical energy or other energy, especially in urban areas where sunlight is limited due to weather and limited airflow for dense dwellings. Natural drying is prohibited in some residential areas for aesthetic reasons $[4,5]$. Housing in densely populated cities in Indonesia does not provide enough space to dry clothes naturally. Some parts around the house, such as windows, balconies, garages, front gates, and others are used to dry clothes. This drying method interferes with aesthetics [6].

Drying is a complex process and requires a lot of energy [7]. Drying is a process of reducing water content by evaporation and using a certain amount of energy to overcome the latent heat of evaporation. The drying process takes place in two stages. The first step is drying on the surface of the material at a constant drying rate and thereby evaporation of water into the environment. The second step corresponds to the properties of the drying product with a decrease in drying rate [8]. When material which has a water content is subjected to hot air, heat transfer will occur on the surface of the material. The temperature of the material will increase, and the water content in the material will evaporate to the surrounding environment. The drying process is related to the mass transfer of water content from the material to the surrounding environment [9]. 
Clothes drying is one of the important applications in drying [10], it is applied in daily life [11] and is one of the domestic sector that consumes very large amounts of energy [6]. Household clothes dryers are one of the most energy-efficient appliances in the housing sector [12]. A quick drying device for clothes is a clothes dryer that uses electricity to dry clothes automatically. This device is a multifunctional machine that is environmentally friendly and saves space that solves the problem of drying clothes on rainy days especially in humid areas or there is not enough space to hang clothes [13]. Clothes dryers are relatively poorly studied in their environmental aspects or improvements in design and efficiency [12].

The high energy consumption for drying clothes encourages innovation in engineering applications. Conventional domestic electric dryers are too expensive and inefficient. Innovations to reduce energy loss and heat recovery are important research topics at this time [6]. The growth of the laundry business in Indonesia uses electricity, kerosene, and natural gas as energy sources. This is predicted as a significant consumption of fossil fuels [7]. The investment value of the dryer is relatively expensive, and energy must be purchased so that operational laundry costs become expensive. Efforts that can be done are to recover wasted energy into useful energy to meet energy needs [14].

One source of energy that can be utilized is the exhaust heat of the air conditioner/air conditioner condenser. AC is widely used in Indonesia as an air conditioner. Research on the use of AC heat for drying clothes has been carried out for experimental studies [9], investigations of aspects of thermodynamics [15], performance with cabinet dryers [6], potential energy utilization [14], closed-cycle cycle drying [16] and making dryers portable [17].

The results showed that the rate of drying clothes using AC exhaust heat tends to be higher than natural drying indoors or drying using commercial dryers [9]. This drying method is very reliable, especially in crowded residential areas, without additional electricity costs [14]. A drying chamber with a volume of $1 \mathrm{~m}^{3}$ is capable of drying materials as much as 6 to $8 \mathrm{~kg}$ [6]. The use of waste heat also has economic advantages over the use of LPG or electricity [12].

This description shows that the application of $A C$ exhaust heat is interesting to study material. For this reason, research concept is needed that aims to utilize hot air discharging air conditioning as an energy source for drying clothes.

\section{Methodology}

Utilization of AC exhaust heat is done by creating a drainage heat channel into the clothes dryer. This utilization uses the principle of isentropic compression work. The research concept is based on an AC device with the following specifications [18]:

Table 1. AC specifications

\begin{tabular}{ll}
\hline \multicolumn{1}{c}{ Description } & \multicolumn{1}{c}{ Specifications } \\
\hline Capacity & $3 / 4 \mathrm{HP}$ \\
Power source & $220-240$ volt AC/50 Hz/1 phase \\
Power consumption & $0.62 \mathrm{~kW}$ \\
Refrigerant & $\mathrm{R} 22$ \\
& Dimensions H/W/D 250/740/185mm \\
& net weight $8 \mathrm{~kg} /$ air volume high fan $/$ medium fan $/ \mathrm{low}$ fan : \\
Indoor unit & $510 / 430 / 350 \mathrm{~m} / \mathrm{h}$ \\
& Dimensions H/W/D: $530 / 660 / 240 \mathrm{~mm} /$ net weight $25 \mathrm{~kg} /$ airflow \\
Outdoor unit & volume: $1580 \mathrm{~m}^{3} / \mathrm{h}$ \\
Compressor output & $606 \mathrm{~W} /$ outdoor temperature range $21-43^{\circ} \mathrm{C}$ \\
\hline
\end{tabular}


This specification data is used in the initial calculation as an initial concept to determine the feasibility of the design based on the amount of heat energy that can be used in the drying process.

\section{Result And Discussion}

The first step of the AC cloth drying feasibility study is carried out by calculating the cooling capacity with the following equation [15]:

$$
Q_{\text {out }}=m \mathrm{Cp}_{\text {air }}\left(\mathrm{T}_{\text {out }}-\mathrm{T}_{\text {in }}\right)
$$

With:

$\mathrm{m}=$ hot air flow rate $\left(\mathrm{kg} / \mathrm{m}^{2} \mathrm{~s}\right)$

$\mathrm{Cp}=$ specific heat of hot air $(\mathrm{J} / \mathrm{kg} \mathrm{K})$

$\mathrm{T}_{\text {out }}=$ outlet temperatur $\left({ }^{\circ} \mathrm{C}\right)$, which hot air Temperature out from AC

$\mathrm{T}_{\text {in }}=$ intlet temperatur $\left({ }^{\circ} \mathrm{C}\right)$, which surrounding temperature

From the outdoor unit air flow rate of $1,580 \mathrm{~m} 3 / \mathrm{H}(0,44 \mathrm{~m} 3 / \mathrm{s})$, the hot air mass flow rate is calculated with the following equation:

$$
m_{\text {air }}=\mathrm{A} \rho \cup(\mathrm{kg} / \mathrm{s})
$$

With:

$$
\begin{array}{ll}
A & =\text { cross-sectional area }\left(\mathrm{m}^{2}\right) \square=\text { air density }\left(\mathrm{kg} / \mathrm{m}^{3}\right) \\
\mathrm{v} & =\text { volume flow rate }\left(\mathrm{m}^{3} / \mathrm{s}\right)
\end{array}
$$

With a cross-sectional area based on the cross-sectional area of hot air out of AC of 0.24 $\mathrm{m}^{2}$ (based on $60 \mathrm{~cm}$ of length and $40 \mathrm{~cm}$ of width), taken for a temperature of $30^{\circ} \mathrm{C}$ of $1,164 \mathrm{~kg} / \mathrm{m}^{3}$ and the flow rate based on AC specifications of $1580 \mathrm{~m}^{3} / \mathrm{h}\left(0.44 \mathrm{~m}^{3} / \mathrm{s}\right)$ then the hot air mass flow rate is obtained:

$$
\begin{aligned}
m_{\text {air }}= & 0.24 \times 1.164 \times 0.44 \\
& =122.61 \mathrm{~kg} / \mathrm{s}
\end{aligned}
$$

With a specific heat of water value of $1,007 \mathrm{~J} / \mathrm{kg} \mathrm{K}(3,689 \mathrm{~J} / \mathrm{kg} \mathrm{C})$ and a maximum hot air temperature taken out of $43^{\circ} \mathrm{C}$ and an air temperature of around $30^{\circ} \mathrm{C}$ then the cooling capacity is obtained:

$$
\begin{aligned}
Q_{\text {out }}= & 122.61 \times 3.689 \times(43-30) \\
& =5.88 \mathrm{~kJ} / \mathrm{s}(5.88 \mathrm{~kW})
\end{aligned}
$$

Furthermore, the coefficient of performance (COP) calculation is done, namely the ratio of cooling capacity and power consumption with the equation:

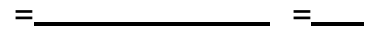

With a power consumption data of $0.62 \mathrm{~kW}(620 \mathrm{~W})$ and a cooling capacity of $11.76 \mathrm{~kW}$, COP is obtained:

$$
\begin{aligned}
\mathrm{COP} & =0.62 / 5.88 \\
& =0.11
\end{aligned}
$$


The COP value is then used to calculate the heating effect available for drying with the equation:

$$
H e=(C O P C+1) P C
$$

With:

$$
\mathrm{Pc}=\text { power compressor }(\mathrm{kW})
$$

With a COP value and a compressor power of $606 \mathrm{~W}(0.606 \mathrm{~kW})$, the heating effect is obtained:

$$
\begin{aligned}
\mathrm{He}= & (0.11+1) 0.606 \\
= & 0.67 \mathrm{~kW}
\end{aligned}
$$

The results of this calculation are in accordance with the specifications of the AC power consumption used. This heating effect corresponds to the average energy consumption of the split air conditioner without dryer is about $0.807 \mathrm{kWh}$ for 85 minutes running time at a temperature of $17^{\circ} \mathrm{C}$ [15]. This shows that the concept of $A C$ hot air application is in accordance with existing references.

Furthermore, the calculation of the rate of heat transfer that can be used based on air temperatures around $30^{\circ} \mathrm{C}$ using equation (1). Take the value of the temperature of the hot air coming out of the air conditioner is $30-43^{\circ} \mathrm{C}$. With these quantities, the heat transfer rate is obtained as a representation of the amount of energy that can be used for the drying process of a minimum of $0.90 \mathrm{~kW}$ and a maximum of $11.76 \mathrm{~kW}$.

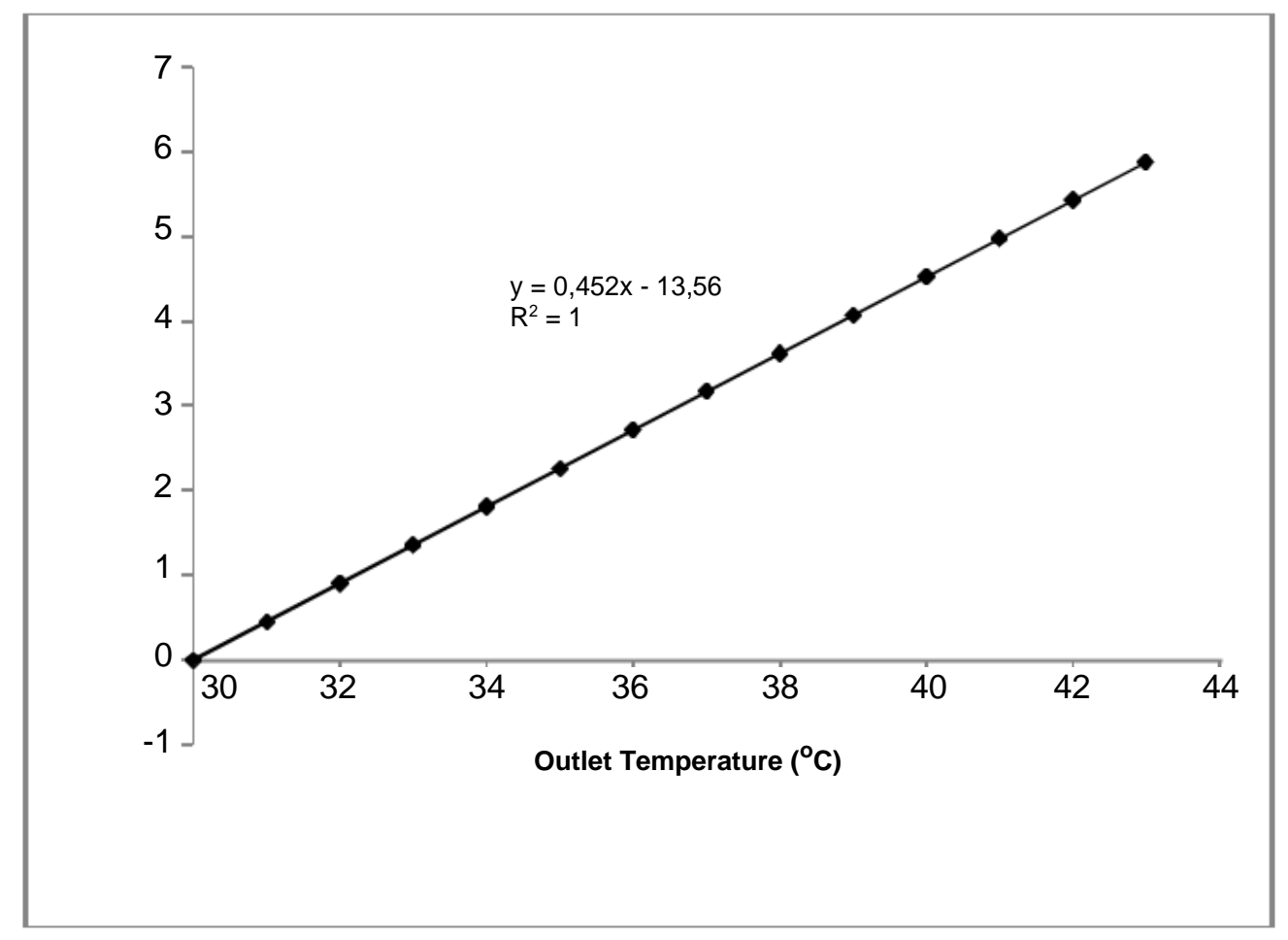

Figure 1. Heat transfer rate 
The graph in Figure 1 above shows that the rate of heat transfer of AC exhaust air has a linear relationship pattern with the temperature of the hot air coming out. This relationship pattern can also be developed for COP values as has been done by reference [11]. This graph can be used as an initial prediction of the range of heat transfer rates that can be utilized. In addition, this information can be used as a comparison for future experimental test results.

The design of the clothes dryer model uses energy sources from the utilization of hot air discharged Air Conditional (AC) shown in FIGURE 1. There are three main parts of the design. The three sections are outdoor air conditioning units, heat flow channels, and drying cabinet. The heat flow channel is adapt to AC outlet cross section which is $40 \mathrm{~cm}$ in width and $60 \mathrm{~cm}$ in length. Outdoor AC unit commonly placed in wall with certain height. Mostly, outdoor unit is placed next below to room ceiling which house or room in Indonesia has average height of 3 meter. This height shows that there is plenty room for drying cabinet.

The use of $\mathrm{AC}$ with a power specification of $3 / 4 \mathrm{HP}$ and a power consumption of 0.62 $\mathrm{kW}(620 \mathrm{~W})$ is carried out with the consideration that this type of $A C$ is widely used in domestic sector. AC with a power of $1 / 2 \mathrm{HP}$ has been studied experimentally to dry clothes up to $5.69 \mathrm{~kg}$ optimally [16]. AC with $1 \mathrm{HP}$ can dry more than $5 \mathrm{~kg}$ of wet towels [17]. Whereas a dryer using a heater and fan with a power consumption of $380 \mathrm{~W}$ can function well for $10 \mathrm{~kg}$ of clothing [19].

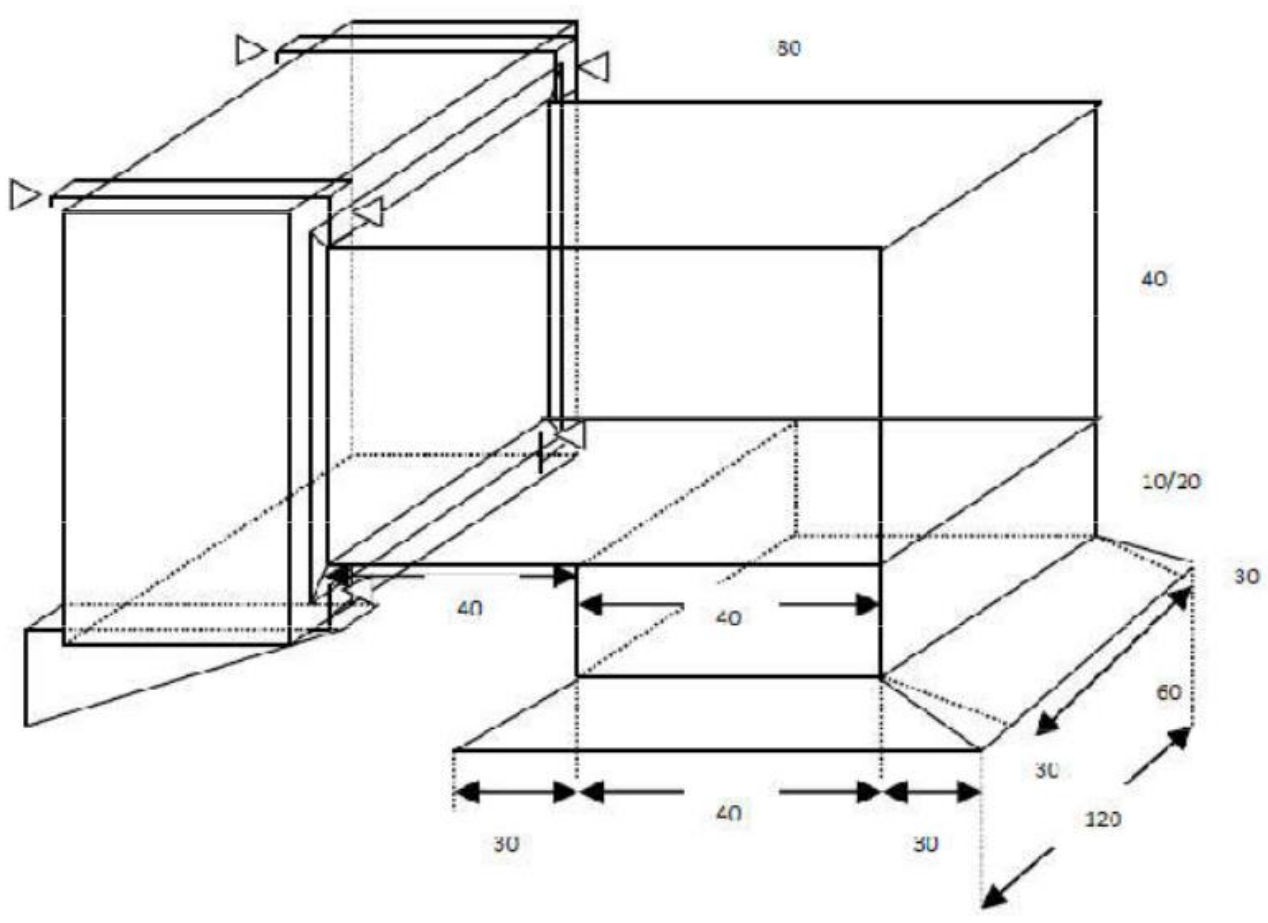

Figure 2. Heat flow channel design 


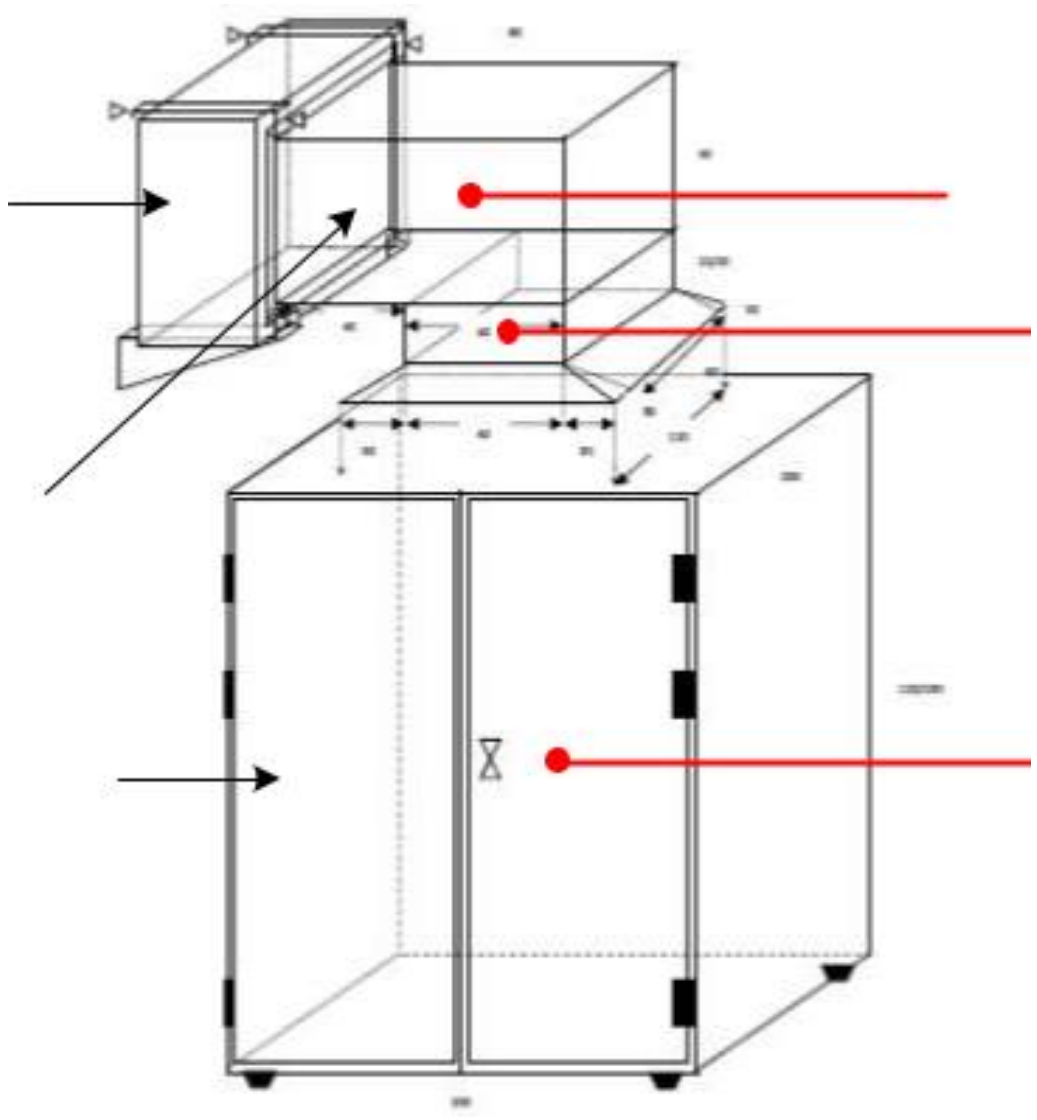

Figure 3. Design of project

Data collection for the experiments can carried out to measure the temperature of hot air intake and drying room air to obtain temperature differences. The digital anemometer can used to calculate the speed of hot airflow to get the mass airflow rate. The mass flow rate and temperature difference are used to get the mass transfer rate of the hot air as a representation of the amount of energy used in the drying process. Measurement of airflow velocity can conduct using a digital anemometer. The velocity is used to calculate the mass flow rate of hot air as in equation (2). The measurement of temperature in and out using a digital thermocouple. The measurement results are used to calculate the temperature difference. The results of the two equations are used to calculate the rate of heat transfer as in equation 1.

Experiments were also carried out by drying a number of wet clothes in the drying chamber. The mass of wet clothing and the mass after the drying process for a certain time must be measured to get the amount of water that has evaporated. The number of evaporated water is used to obtain specific moisture extraction (SMER) as a characteristic that represents the effectiveness of the energy used in the drying process. SMER is obtained by equation:

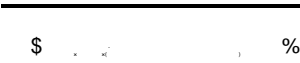


With:

$\mathrm{X}=$ moisture removed $(\mathrm{kg})$

The results of the analysis above show that the utilization of air conditioning heat waste as cloth drying energy sources has the potential to be developed. This is very suitable with the problem of drying clothes, especially for the needs of household life in dense settlements. Further development will be carried out with the application of microcontrollers, especially Arduino devices such as research conducted by reference [1, 2].The application of the control system can be used to control the temperature so that the drying process can take place optimally and can prevent excessive drying process that can risk damaging the dried clothes.

\section{Conclusion}

The results of the concept design of the use of hot air-conditional (AC) as a source of drying clothes is very potential. Outlet air from AC unit is a hot air which has amount of energy in heat form that can be used as drying energy. The amount of energy is shown as the heating effect. Experimental study can be done by design of apparatus based on AC specifications and outlet dimensions. Several measurements such as air temperature, flow velocity, and clothes mass should be done to get drying performance.

\section{REFERENCES}

1. M. M. Febrianto, F. M. Akbar, J. Bintoro, 2017, Prototipe Alat Pengering Pakaian Berbasis Arduino Uno, Jurnal Autocracy 4(1): pp. 1-9.

2. A. S. Lehman, J. Sanjaya, 2018, Automatic Clothes Dryer Using Microcontroller, Prosiding Seminar Nasional Pendidikan Teknik Informatika (SENAPATI) Ke-9, Bali, 08 September 2018, ISSN 2087-2658: pp. 147-151.

3. S. O. Amiebenomo, I. I. Omorodion, J.O. Igbinoba, 2013, Prototype Design and Performance Analysis of Solar Clothes Dryer, Asian Review of Mechanical Engineering 2(1): pp. 35-43.

4. Malave A.C, Kharade Sandesh Arun, Runmode Nitin Chandrakant, Namdas Sachin Suresh, Narute Sandeepkumar Lalaso, 2017, Review Paper on Design and Fabrication of Cloths Drying Machine, International Journal of Engineering Science and Computing 7(4): pp. 10440-10441.

5. Bhushan D. Dahake, Narendra R. Deore, 2017, Design and Analysis of Clothes Dryer, International Engineering Research Journal Special Edition PGCON-MECH2017: pp. 1-7.

6. H. Ambarita, A. H. Nasution, N. M. Siahaan, H. Kawai, 2016, Performance of a clothes drying cabinet by utilizing waste heat from a split-type residential air conditioner, CaseStudiesinThermalEngineering8(2016): pp. 105-114.

7. J-W. Peng, C-L. Zhang, X. Cao, 2017, Modeling and Analysis of a Heat Pump Clothes Dryer, $12^{\text {th }}$ IEA Heat Pump Conference (2017) Rotterdam: pp. 1-10.

8. Kalyankar A.N, Kedar A.R, Khandekar P.S, Jadhav J.J, Jadhav S.D, Kale B.R, 2018, Electric clothes dryer and dehydrator, International Research Journal of Engineering and Technology (IRJET) 05(03): pp. 3813-3816

9. B. Setyawan, M. A. Irfa'i, 2015, Rancang Bangun Pengering Pakaian Kapasitas 10 kg Berdaya 380 Watt, JRM 02(02): pp. 17-20.

10. A. H. Nasution, P. G. Sembiring, H. Ambarita, 2018, Effectiveness of a heat exchanger in a heat pump clothes dryer,IOP Conf. Series: Materials Science and Engineering $308(2018) 012027$ doi:10.1088/1757-899X/308/1/012027, $10^{\text {th }}$ International Conference Numerical Analysis in Engineering: pp. 1-9.

11. P. Suntivarakorn, S. Satmarong, C. Benjapiyaporn, and S. Theerakulpisut, 2009, An Experimental Study on Clothes Drying Using Waste Heat from Split Type Air Conditioner, International Scholarly and Scientific Research \& Innovation 3(5): pp. 483-488. 
12. J. Lee, N. Hoeller, D. Rogers, S. Musnier, F.A. Salustri, 2009, An Empirical Study of Energy Efficiency of Clothes Dryers, Proceeding of International Conference On Engineering Design, ICED'09, Stanford University, Stanford, CA, USA.

13. S. Yao-jun, Wu.-qun, Dai Ye, 2015, Research on Innovative Design of Portable Quick-drying Machine, International Journal of Control and Automation 8(1): pp. 149156.

14. N. Suarnadwipa, I W. Bandem Adnyana, 2017, Potensi Pemanfaatan Energi Buangan Kondensor Untuk Pengeringan Pakaian, ProsidingSeminar Nasional Sains dan Teknologi (Senastek) IV, Bali, Indonesia 2017

15. T. M. I. Mahlia, C. G. Hor, H. H. Masjuki, M. Husnawan, M. Varman and S. Mekhilef, 2010, Clothes Drying From Room Air Conditioning Waste Heat: Thermodynamics Investigation, The Arabian Journal for Science and Engineering 35(1B): pp. 339-351.

16. Gordon HTTM, A. Aziz, R. I. Mainil, 2017, Karakteristik Pengujian Pada Mesin Pengering Pakaian Menggunakan Air Conditioner (AC) 1/2 PK Dengan Siklus Udara Tertutup, Jurnal Sains dan Teknologi 16(1): 24-30 P-ISSN 1412-6257 E-ISSN 25499742.

17. R. Berutu, Immanuel S, A. Heryanto, A. H. Nasution, E. Y Setyawan, 2019, Alat Pengering Pakaian Portable dengan Memanfaatkan Energi Panas Buangan AC Split 1 PK, Jurnal Flywheel 9(2): pp. 24-29.

18. Toshiba Service Manual: Air Conditioner Split wall Type, April 2008.

19. B. Setyawan, M. A. Irfa'i, 2015, Rancang Bangun Pengering Pakaian Kapasitas 10 Kg Berdaya 380 watt, JRM 02(02): pp. 17-20 